\title{
Antioxidant Sensors Based on DNA-Modified Electrodes
}

\author{
Jifeng Liu,† Christophe Roussel,† Grégoire Lagger,‡ Philippe Tacchini,‡ and Hubert H. Girault*,† \\ Laboratoire d'Electrochimie Physique et Analytique, Ecole Polytechnique Féderale de Lausanne, Station 6, \\ CH-1015, Lausanne, Switzerland, and EDEL Therapeutics SA, PSE-B, Ecole Polytechnique Féderale de Lausanne, \\ $\mathrm{CH}-1015$, Lausanne, Switzerland
}

$\mathrm{TiO}_{2} / \mathrm{ITO}$ modified electrodes were developed to quantitatively photooxidize adsorbed ds-DNA and to study the effect of antioxidants as ds-DNA protecting agents. $\mathrm{TiO}_{2}$ films are used for efficient ds-DNA immobilization, for dsDNA oxidation through photogenerated hydroxyl radicals, and as electrodes for amperometric sensing. The films, prepared by a sol-gel process, are deposited on ITO glass electrodes. Damages occurring after ds-DNA oxidation by ROS are detected by adding MB as an intercalant probe and by monitoring the electrochemical reduction current of the intercalated redox probe. The MB electrochemical signal is found to be sensitive enough to monitor ds-DNA structure changes, and the electrochemical sensor has been applied to the evaluation of the antioxidant properties of glutathione and gallic acid.

DNA sensors comprise many different devices used in fields as varied as hybridization assays, ${ }^{1-6}$ identification and quantification of DNA molecules in disease diagnostics, detection of pathogenic organisms, ${ }^{7-11}$ detection of toxins, ${ }^{12}$ and antioxidant tests. ${ }^{13,14}$ Electrochemical DNA sensors should meet general specifications, such as rapid detection, sensitivity, low power consumption, low cost, and mass production, as recently

\footnotetext{
* To whom correspondence should be addressed. E-mail: hubert.girault@ epfl.ch.

${ }^{\dagger}$ Laboratoire d’Electrochimie Physique et Analytique.

* EDEL Therapeutics SA.

(1) Lucarelli, F.; Marrazza, G.; Turner, A. P. F.; Mascini, M. Biosens. Bioelectron. 2004, 19, 515-530.

(2) Immoos, C. E.; Lee, S. J.; Grinstaff, M. W. J. Am. Chem. Soc. 2004, 126, 10814-10815.

(3) Guedon, P.; Livache, T.; Martin, F.; Lesbre, F.; Roget, A.; Bidan, G.; Levy, Y. Anal. Chem. 2000, 72, 6003-6009.

(4) Xu, X. H.; Bard, A. J. J. Am. Chem. Soc. 1995, 117, 2627-2631.

(5) Xu, X. H.; Yang, H. C.; Mallouk, T. E.; Bard, A. J. J. Am. Chem. Soc. 1994, 116, 8386-8387.

(6) Carter, M. T.; Bard, A. J. Bioconjugate Chem. 1990, 1, 257-263.

(7) Baeumner, A. J.; Pretz, J.; Fang, S. Anal. Chem. 2004, 76, 888-894.

(8) Zhang, Y. C.; Kim, H. H.; Heller, A. Anal. Chem. 2003, 75, 3267-3269.

(9) Campbell, C. N.; Gal, D.; Cristler, N.; Banditrat, C.; Heller, A. Anal. Chem. 2002, 74, 158-162.

(10) Popovich, N. D.; Eckhardt, A. E.; Mikulecky, J. C.; Napier, M. E.; Thomas, R. S. Talanta 2002, 56, 821-828.

(11) Armistead, P. M.; Thorp, H. H. Bioconjugate Chem. 2002, 13, 172-176.

(12) Lucarelli, F.; Palchetti, I.; Marrazza, G.; Mascini, M. Talanta 2002, 56, $949-$ 957.

(13) Bukova, M.; Labuda, J.; Sandula, J.; Krizkova, L; Stepanek, I.; Durackova, Z. Talanta 2002, 56, 939-947.

(14) Labuda, J.; Buckova, M.; Heilerova, L.; Caniova-Ziakova, A.; Brandsteterova, E.; Mattusch, J.; Wennrich, R. Sensors 2002, 2, 1-10.
}

reviewed. ${ }^{15-18}$ Usually, electrochemical signals pertaining to DNA detection are obtained either directly from the oxidation of the DNA bases or indirectly using DNA-specific redox active indicators, DNA-mediated redox reporters, or enzymes immobilized upon DNA hybridization. ${ }^{15}$ One of the key features for the design of such a biosensor is the efficient attachment of DNA onto the electrode surface through specific linkages. Classic immobilization procedures used in DNA sensor technology are based on the adsorptive accumulation of DNA on carbon, bulk-modification of a carbon paste electrode, carbodiimide covalent binding, attachment of biotinylated probes to an avidin-coated surface, attachment to polymer-coated surfaces, and direct self-assembly of thiolated probes ${ }^{1}$.

DNA oxidation sensors represent a class of sensor to monitor the degree of DNA oxidation. They are based on polymer-modified electrodes ${ }^{19}$ and disposable carbon screen printed electrodes. ${ }^{12-14,20}$ In the latter case, DNA was immobilized onto the electrode surface by electrocoating ${ }^{12,20}$ or by dip-coating. ${ }^{13,14}$ Another DNA oxidation sensor based on direct DNA adsorption on a mercury electrode ${ }^{21,22}$ has been also proposed. DNA oxidation was promoted by an electrochemically induced Fenton reaction and monitored by the signal of a specific tensametric peak or by the electrochemistry of reducible adenine and cytosine residues. ${ }^{21,22}$ More recently, an electrochemiluminescent method for oxidized DNA detection was also reported. ${ }^{23}$

Nucleic acids can be oxidized by various oxidants and in particular by ROS. Cellular DNA oxidation by ROS always results in DNA bases being damaged, which has been acknowledged as a significant source of mutations leading to cancer, premature aging and other degenerative diseases. ${ }^{24}$ In living systems,

(15) Drummond, T. G.; Hill, M. G.; Barton, J. K. Nat. Biotechnol. 2003, 21, 11921199.

(16) Gooding, J. J. Electroanalysis 2002, 14, 1149-1156.

(17) Palecek, E.; Jelen, F. Crit. Rev. Anal. Chem. 2002, 32, 261-270.

(18) Wang, J. Anal. Chim. Acta 2002, 469, 63-71.

(19) Mugweru, A.; Wang, B. Q.; Rusling, J. Anal. Chem. 2004, 76, 5557-5563.

(20) Wang, J.; Rivas, G.; Ozsos, M.; Grant, D. H.; Cai, X. H.; Parrado, C. Anal. Chem. 1997, 69, 1457-1460.

(21) Fojta, M.; Kubicarova, T.; Palecek, E. Biosens. Bioelectron. 2000, 15, 107115.

(22) Palecek, E.; Fojta, M.; Tomschik, M.; Wang, J. Biosens. Bioelectron. 1998, 13, 621-628.

(23) Dennany, L.; Forster, R. J.; White, B.; Smyth, M.; Rusling, J. F. J. Am. Chem. Soc. 2004, 126, 8835-8841.

(24) Helbock, H. J.; Beckman, K. B.; Shigenaga, M. K.; Walter, P. B.; Woodall, A. A.; Yeo, H. C.; Ames, B. N. Proc. Natl. Acad. Sci. U.S.A. 1998, 95, $288-$ 293.

Analytical Chemistry, Vol. 77, No. 23, December 1, 20057687 

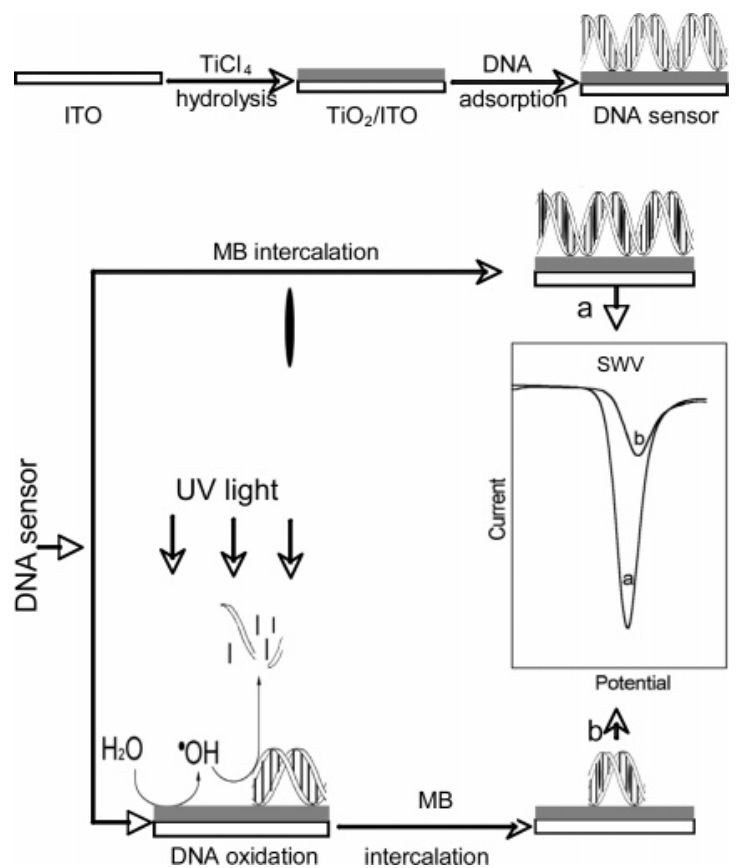

Figure 1. Schematic diagram of ds-DNA/(TiO $)$ i/lTO sensor principle.

superoxide radicals $\left(\mathrm{O}_{2}^{-\bullet}\right), \mathrm{H}_{2} \mathrm{O}_{2}$, and hydroxyl radicals $\left(\mathrm{OH}^{\bullet}\right)$ are the main ROS produced in normal metabolism. ${ }^{25}$ In addition to the destruction and release of the nucleobases, hydroxyl radicals also attack the deoxyribose moieties of DNA, resulting in double strand breaking (DSB), which causes interruption of the phosphodiester bonds. ${ }^{26}$ Products coming from the oxidation of DNA bases and DNA strand breaking have received particular attention. For example, more than 26 oxidized bases were identified after oxidation ${ }^{27}\left(\mathrm{OH}^{\circ}\right.$, Fenton-type reaction). $\mathrm{TiO}_{2}$-based materials have been investigated also for the photocatalytic oxidation of DNA, causing breakage and mineralization of nucleic acids strands ${ }^{28}$ through $\mathrm{ROS}$ generation, ${ }^{29}$ underlining that $\mathrm{TiO}_{2}$ electrode materials are suitable for the immobilization and oxidation of biomolecules.

We present herein a ds-DNA oxidation sensor based on modified $\mathrm{TiO}_{2} / \mathrm{ITO}$ electrodes in which the $\mathrm{TiO}_{2}$ coating, obtained by sol-gel process, plays the role of ds-DNA immobilization substrate, photoanode for ROS $\left(\mathrm{OH}^{\circ}\right)$ generation, and electrode for the monitoring of intercalated redox probes by voltammetry. The gist of this sensor is to adsorb ds-DNA on $\mathrm{TiO}_{2}$ electrodes and to irradiate the ds-DNA-coated $\mathrm{TiO}_{2}$ electrodes with UV light. The resulting ds-DNA oxidation damages are monitored by electrochemistry, by transferring the electrode in a MB solution, and by monitoring the surface concentration of the redox probe intercalated in the remaining ds-DNA. The proposed ds-DNA oxidation sensor, depicted in Figure 1, has been used to compare the antioxidant properties of glutathione and gallic acid.

(25) Valentao, P.; Fernandes, E.; Carvalho, F.; Andrade, P. B.; Seabra, R. M.; Bastos, M. L. J. Agric. Food Chem. 2002, 50, 4989-4993.

(26) Portugal, J.; Waring, M. J. FEBS Lett. 1987, 225, 195-200.

(27) Luo, Y. Z.; Henle, E. S.; Linn, S. J. Biol. Chem. 1996, 271, 21167-21176.

(28) Hidaka, H.; Horikoshi, S.; Serpone, N.; Knowland, J. J. Photochem. Photobiol., A 1997, 111, 205-213.

(29) Nagaveni, K.; Hegde, M. S.; Ravishankar, N.; Subbanna, G. N.; Madrao, G. Langmuir 2004, 20, 2900-2907.

\section{EXPERIMENTAL SECTION}

Chemicals and Materials. Salmon testes ds-DNA sodium salt (dissolved in water at $1.7 \mathrm{mg} / \mathrm{mL}$ ), $\mathrm{MB}$, and glutathione were purchased from Sigma. $\mathrm{TiCl}_{4}$ (at $2 \mathrm{M}$ in water prepared as follows: The required amount of water is first frozen and $\mathrm{TiCL}_{4}$ is slowly added. The resulting stock solution is stirred until the end of the $\mathrm{HCl}$ generation and stored at $-20^{\circ} \mathrm{C}$ ) and terephthalic acid (dissolved into a $4 \mathrm{mM} \mathrm{NaOH}$ aqueous solution at a final concentration of $0.4 \mathrm{mM}$ ) were from Fluka. Gallic acid was obtained from Acros. ITO pieces of $42 \mathrm{~mm}^{2}$ of surface area (resistance $<20 \Omega$ /square, $15 \times 7 \mathrm{~mm}$ ), used as working electrodes, were obtained from Merck. The PBS buffer was made of sodium phosphate $\left(\mathrm{NaH}_{2} \mathrm{PO}_{4} / \mathrm{Na}_{2} \mathrm{HPO}_{4}, 81: 19\right.$ (molar ratio)) and $\mathrm{NaCl}$ dissolved in water at final concentrations of 50 and 10 $\mathrm{mM}$, respectively (pH: 7.4). ds-DNA adsorption buffers were citric $(\mathrm{pH}: 2-3)$, acetic (pH: $3.5-5)$, MES (pH: 6) solutions at $50 \mathrm{mM}$ $\mathrm{KCl}$.

$\left(\mathrm{TiO}_{2}\right) \boldsymbol{i} / \mathrm{ITO}$ Electrodes. Before use, the ITO slide is washed in water (under ultrasound for $10 \mathrm{~min}$ ); rinsed with acetone, then with a sodium hydroxide solution at $1 \mathrm{M}\left(\mathrm{H}_{2} \mathrm{O} /\right.$ ethanol 1:1, V/V); and finally, dried at room atmosphere and temperature for $1 \mathrm{~h}$. The resulting ITO glass is immersed into a $25 \mathrm{mM} \mathrm{TiCl}_{4}$ aqueous solution (obtained by dilution of the stock solution) and heated at $70{ }^{\circ} \mathrm{C}$ (room atmosphere) for 30 min. ${ }^{30}$ After washing with $1-2$ $\mathrm{mL}$ of water, the modified $\mathrm{TiO}_{2} / \mathrm{ITO}$ glass is dried at $200{ }^{\circ} \mathrm{C}$ (at room atmosphere) for $5 \mathrm{~min}$. The described sol-gel process could be repeated several times to obtain $\left(\mathrm{TiO}_{2}\right) i /$ ITO electrodes ( $i$ represents the number of coatings). Finally, the $\left(\mathrm{TiO}_{2}\right) i / \mathrm{ITO}$ electrodes are calcinated at $350{ }^{\circ} \mathrm{C}$ (at room atmosphere) for 30 $\mathrm{min}$. The determination of the size of particles constituting the films $(10-15 \mathrm{~nm})$ as well as the thickness of the different coatings (30 $\mathrm{nm}$ for $i=4$ ) were accessed by scanning electron microscopy SEM (SEM, Philips XL 30 SFEG). As an example, Figure 2a and $\mathrm{b}$ presents the SEM micrographs (top view and cross section view, respectively) of a $\left(\mathrm{TiO}_{2}\right)_{4} / \mathrm{ITO}$ modified electrode. The optical quality of the different $\left(\mathrm{TiO}_{2}\right) i$ /ITO electrodes $(1<i<4)$ allows the control of the film growth by UV spectroscopy: the absorbance monitored at $300 \mathrm{~nm}$ increases with $i$. The UV measurements corroborated the SEM data.

ds-DNA Adsorption on $\left(\mathrm{TiO}_{2}\right) \mathbf{i} / \mathrm{ITO}$ Electrodes. The $\left(\mathrm{TiO}_{2}\right) i / \mathrm{ITO}$ electrodes are immersed at $4{ }^{\circ} \mathrm{C}$ overnight in dsDNA stock solutions $(0.43 \mathrm{mg} / \mathrm{mL}$ of ds-DNA in a $\mathrm{pH} 3$ citrate buffer or at the same concentration in buffers ranging from $\mathrm{pH} 2$ to 7.4 for the adsorption study as a function of the $\mathrm{pH}$ ). After washing with water and drying at room atmosphere, the electrodes are heated at $70{ }^{\circ} \mathrm{C}$ for $30 \mathrm{~min}$ to form the modified ds-DNA/ $\left(\mathrm{TiO}_{2}\right) i / \mathrm{ITO}$ electrodes. ${ }^{31}$

ds-DNA Photooxidation on $\left(\mathrm{TiO}_{2}\right) \mathbf{i}$ /ITO Electrodes. ds$\mathrm{DNA} /\left(\mathrm{TiO}_{2}\right) i / \mathrm{ITO}$ electrodes are immersed in a PBS buffer $(\mathrm{pH}$ : 7.4) and illuminated with UV light through the solution (wavelength ranges from 300 to $500 \mathrm{~nm}$ with a maximum peak at 360 $\mathrm{nm}$ and an illumination power on the ds-DNA sensor of $25 \mathrm{~W} / \mathrm{m}^{2}$ ). After a given illumination time, the ds-DNA/ $\left(\mathrm{TiO}_{2}\right) i / \mathrm{ITO}$ elec-

(30) Wang, P.; Zakeeruddin, S. M.; Comte, P.; Charvet, R.; Humphry-Baker, R.; Gratzel, M. J. Phys. Chem. B 2003, 107, 14336-14341.

(31) Brown, G. E.; Henrich, V. E.; Casey, W. H.; Clark, D. L.; Eggleston, C.; Felmy, A.; Goodman, D. W.; Gratzel, M.; Maciel, G.; McCarthy, M. I.; Nealson, K. H.; Sverjensky, D. A.; Toney, M. F.; Zachara, J. M. Chem. Rev. 1999, 99, 77-174. 
trodes are washed with water and are ready for electrochemical studies. All the photocatalytic oxidations were performed in an open system because the room atmosphere provides enough oxygen for an efficient oxidative degradation of ds-DNA.

Electrochemical Characterization of the ds-DNA/ $\left(\mathrm{TiO}_{2}\right) i_{\text {/ }}$ ITO Electrodes. The different ds-DNA-modified electrodes are immersed in an undivided electrochemical cell filled with $2 \mu \mathrm{M}$ $\mathrm{MB}$ in PBS buffer (pH: 7.4) with a platinum wire counter electrode and a homemade reference electrode, $\mathrm{Ag} / \mathrm{AgCl}$ in a saturated $\mathrm{KCl}$ solution. After 3 min (time required to label ds-DNA with $\mathrm{MB}$ ), the electrochemical detection is performed on an Autolab PGSTAT 30 potentiostat (Metrohm). ds-DNA damage is evaluated through measurement of the $\mathrm{MB}$ reduction current and compared with the electrochemical signal recorded with a nonirradiated ds-DNA modified electrode. The electrochemical methods used are SWV (potential step $\Delta E_{\mathrm{s}}=5 \mathrm{mV}$, step amplitude $\Delta E_{\mathrm{sw}}=25 \mathrm{mV}$, and frequency $f=10 \mathrm{~Hz}$ ) and $\mathrm{CV}$ (potential step $\Delta E_{\mathrm{s}}=5 \mathrm{mV}$, scan rate $=50 \mathrm{mV} / \mathrm{s}$ ).

Photocatalytic Properties of $\left(\mathrm{TiO}_{2}\right) \mathrm{i} / \mathrm{ITO}$ Electrodes. The evaluation of the photooxidation properties of the $\left(\mathrm{TiO}_{2}\right) i /$ ITO electrodes was accessed by titration with a fluorescent quencher. ${ }^{32}$ The fluorescence spectra of 2-hydroxyterephthalic acid (generated by the reaction of terephthalic acid with the produced $\mathrm{OH}^{\circ}$ ) were measured on a Perkin-Elmer LS-50B fluorescence spectrometer. The $\left(\mathrm{TiO}_{2}\right) i /$ ITO electrodes were immersed in a solution of terephthalic acid and illuminated at $360 \mathrm{~nm}$ during a given time. After irradiation, the solution is transferred into a quartz cell for fluorescence measurements. The excitation wavelength is $315 \mathrm{~nm}$ and the signal is recorded at $425 \mathrm{~nm}$.

\section{RESULTS AND DISCUSSION}

ROS Generation on $\mathrm{TiO}_{2} /$ ITO Modified Electrodes. The modified $\left(\mathrm{TiO}_{2}\right) i /$ ITO electrodes (as shown in Figure $2 \mathrm{a}$ and $2 \mathrm{~b}$ ), made by successive $\mathrm{TiO}_{2}$ coatings onto ITO electrodes ( $i$ represents the number of dip-coating procedures), are used to generate ROS via the photocatalytic oxidation of water ${ }^{29}$ (Scheme 1) when irradiated at $360 \mathrm{~nm}$. The amount of $\mathrm{OH}^{\bullet}$ produced at the $\left(\mathrm{TiO}_{2}\right)$ il ITO electrodes was followed by fluorescence spectroscopy ${ }^{32}$ (Scheme 2). As shown in Figure 3a and b, the fluorescence rises linearly with the illumination time. The quenching reaction, selective toward $\mathrm{OH} \cdot$ radicals, ${ }^{32}$ allows a direct comparison of the photocatalytic efficiency of the different $\left(\mathrm{TiO}_{2}\right) i /$ ITO electrodes. From these results, it can be concluded that $\left(\mathrm{TiO}_{2}\right)_{4} / \mathrm{ITO}$ electrodes provide the highest $\mathrm{OH}^{\bullet}$ production. These results also show that the ROS production rate is constant for a given illumination fluence.

ds-DNA Adsorption on $\mathrm{TiO}_{2} /$ ITO Modified Electrodes. As already proposed for the adsorption of phosphate derivatives on $\mathrm{TiO}_{2}$ materials, ${ }^{31}$ the ds-DNA/ $\left(\mathrm{TiO}_{2}\right) \mathrm{i} / \mathrm{ITO}$ electrodes were heated at $70{ }^{\circ} \mathrm{C}$ to improve the ds-DNA immobilization. Temperatures ranging from 40 to $70{ }^{\circ} \mathrm{C}$ were tested, and it was observed that a drying procedure performed at $70{ }^{\circ} \mathrm{C}$ leads to an optimum binding and a good conservation of the ds-DNA structure. To check the presence of ds-DNA on the electrode, the ds-DNA/ $\left(\mathrm{TiO}_{2}\right) i / \mathrm{ITO}$ electrode is immersed in a solution of $\mathrm{MB},{ }^{33}$ and the amount of

(32) Ishibashi, K.; Fujishima, A.; Watanabe, T.; Hashimoto, K. Electrochem. Commun. 2000, 2, 207-210.

(33) Kelley, S. O.; Barton, J. K.; Jackson, N. M.; Hill, M. G. Bioconjugate Chem. 1997, 8, 31-37. a)

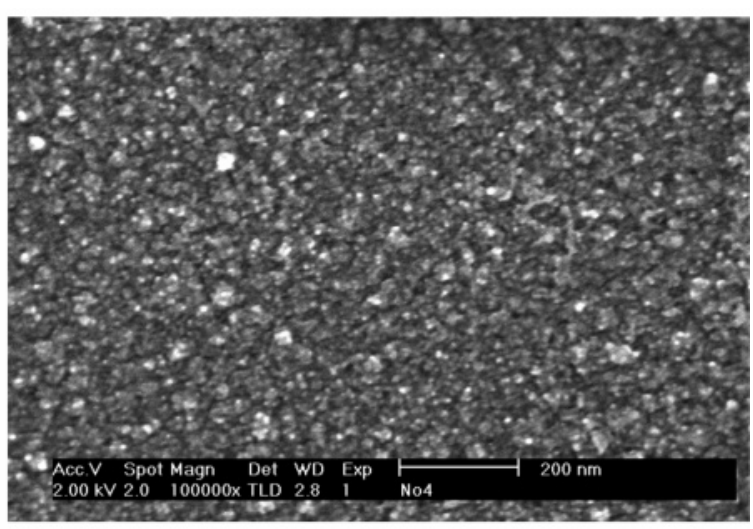

b)

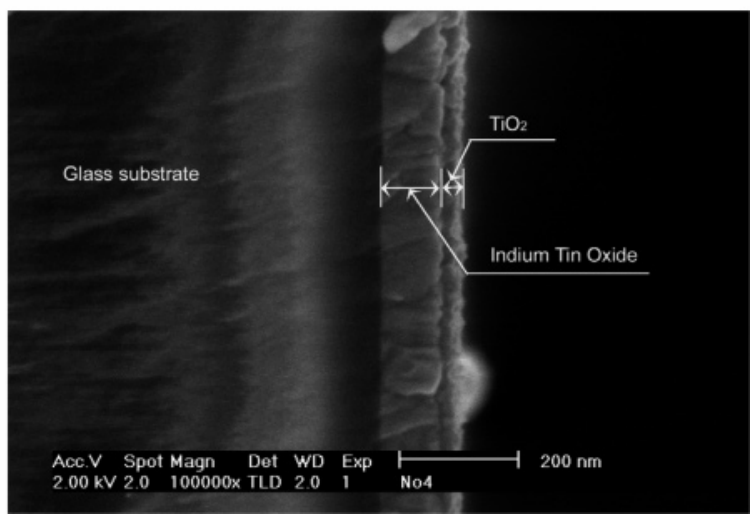

Figure 2. SEM characterization of a $\left(\mathrm{TiO}_{2}\right)_{4} / \mathrm{ITO}$ electrode: (a) surface morphology of the $\mathrm{TiO}_{2}$ film and (b) cross-sectional view of the $\mathrm{TiO}_{2}$ film.

\section{Scheme 1. $\mathrm{TiO}_{2}$ Photocatalytic Oxidation of Water from Ref $29^{a, b}$}

$$
\begin{aligned}
& \mathrm{TiO}_{2}+h v \longrightarrow h_{V B}^{+}+e_{C B}^{-} \\
& h_{V B}^{+}+\mathrm{H}_{2} \mathrm{O}_{(\mathrm{ads})} \longrightarrow \mathrm{OH}^{\bullet}+\mathrm{H}^{+} \\
& h_{V B}^{+}+2 \mathrm{OH}_{(\mathrm{ads})}^{-} \mathrm{OH}^{-}+\mathrm{OH}^{\cdot} \\
& e_{C B}^{-}+\mathrm{O}_{2} \longrightarrow \mathrm{O}_{2}^{\cdot-} \\
& 2 \mathrm{O}_{2}^{-}+2 \mathrm{H}_{2} \mathrm{O} \longrightarrow 2 \mathrm{OH}^{\bullet}+2 \mathrm{OH}^{-}+\mathrm{O}_{2}
\end{aligned}
$$

${ }^{a} h_{\mathrm{VB}}^{+}$: holes created in the valence band of $\mathrm{TiO}_{2}$ films when irradiated at $360 \mathrm{~nm}^{b} e_{\mathrm{CB}}^{-}$: electrons transferred in the conducting band of $\mathrm{TiO}_{2}$ films when irradiated at $360 \mathrm{~nm}$.

intercalated probe molecules is quantified by voltammetry. ${ }^{34}$ This well-known electroactive ds-DNA intercalant was chosen for its good binding properties (binding constant from $\approx 10^{5}$ to $\approx 10^{6} \mathrm{M}^{-1}$, depending on the detection method ${ }^{33,34}$ ), its high sensitivity toward ds-DNA structure changes (even single mismatches could be detected $^{35}$ ), and its formal redox potential slightly dependent on $\mathrm{pH}$ (from -0.1 to $-0.4 \mathrm{~V} / \mathrm{SCE}$ for $\mathrm{pH}$ from 4 to $11^{36}$ ). CVs displayed in Figure 4 show that the peak intensity for MB reduction is directly proportional to the scan rate (Figure 4 inset) that indicates that voltammetric measurements in a MB solution monitors mainly the surface-bound $\mathrm{MB}$ and is less sensitive to the bulk concentration. The amount of adsorbed ds-DNA is then considered as directly proportional to the reduction current of $\mathrm{MB}$

(34) Tuite, E.; Kelly, J. M. Biopolymers 1995, 35, 419-433.

(35) Kelley, S. O.; Boon, E. M.; Barton, J. K.; Jackson, N. M.; Hill, M. G. Nucleic Acids Research 1999, 27, 4830-4837.

(36) Erdem, A.; Kerman, K.; Meric, B.; Akarca, U. S.; Ozsoz, M. Anal. Chim. Acta 2000, 422, 139-149. 
Scheme 2. OH· Quenching by Terephthalic Acid, from Ref $3^{a}$

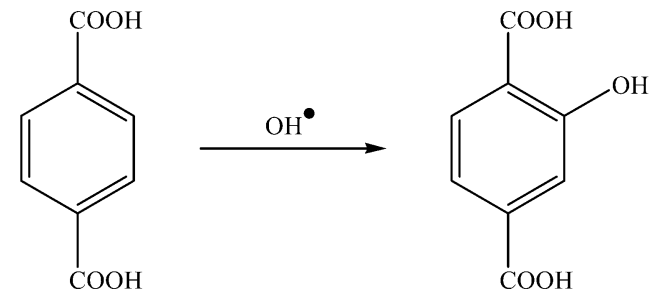

Terephthalic acid

2-hydroxyterephthalic acid

a The amount of $\mathrm{OH}^{\cdot}$ radicals produced at the $\left(\mathrm{TiO}_{2}\right)$ i/lTO electrodes is monitored through the fluorescence signal of 2-hydroxyterephthalic acid.

bound to the ds-DNA on the electrode. Experiments performed on bare $\left(\mathrm{TiO}_{2}\right) i / \mathrm{ITO}$ electrodes highlight the diffusion-controlled reduction of $\mathrm{MB}$ (no adsorption of $\mathrm{MB}$ at the electrode surface) in the absence of adsorbed ds-DNA (Figure S-1).

The influence of the $\mathrm{pH}$ of the ds-DNA coating solution on the quantity of adsorbed ds-DNA at the $\left(\mathrm{TiO}_{2}\right) i / \mathrm{ITO}$ electrodes was also studied (Figure 5). From pH 6 to 4, the MB reduction current is constant and rather low, then revealing a low but equal amount of ds-DNA adsorbed at the electrode surface in this $\mathrm{pH}$ range. These observations could be directly compared to the weak adsorption process occurring between phosphate diester derivatives (a structure close to the phosphodiester group of ds-DNA nucleotides) and $\mathrm{TiO}_{2}$ films at $\mathrm{pH} 6 .{ }^{37} \mathrm{In}$ this $\mathrm{pH}$ range, $\mathrm{TiO}_{2}$ is weakly positively charged (the zero point charge of $\mathrm{TiO}_{2}$ ranges from 5.0 to 6.7 , depending on crystallographic structures ${ }^{38}$ ), whereas ds-DNA is highly negatively charged. ${ }^{39}$ When going toward more acidic conditions, the adsorption increases until $\mathrm{pH}$ 2. At this $\mathrm{pH}$, the strong ds-DNA/ $/ \mathrm{TiO}_{2}$ interactions could be reasonably attributed to attractive electrostatic forces between the highly negatively charged ds-DNA (the $\mathrm{pK}$ of the phosphodiester group is around ${ }^{39}$ ) and the positively charged $\mathrm{TiO}_{2}$ film surface (presence of $\mathrm{TiOH}_{2}{ }^{+}$and $\mathrm{Ti}-\mathrm{OH}^{+}-\mathrm{Ti}$ groups ${ }^{40}$ ). No experiment was done at $\mathrm{pH}<2$ because of a possible ds-DNA structure alteration. ${ }^{39,41}$ The conservation of the ds-DNA structure after adsorption at $\mathrm{pH} 2$ and thermal treatment $\left(70^{\circ} \mathrm{C}\right)$ was verified by $\mathrm{CV}$, as shown in Figure 4.

The influence of the $\mathrm{TiO}_{2}$ film thickness on the amount of adsorbed ds-DNA onto $\left(\mathrm{TiO}_{2}\right) i$ /ITO electrodes was also studied by SWV. When $i$ varies from 1 to 3 , the MB reduction current increases as the specific surface area and, therefore, the amount of immobilized ds-DNA on the electrode surface increases. These observations are in agreement with the rise of the binding sites at the electrode surface within the film thickness and roughness. For $i>3$, a MB reduction potential shift is observed (MB is reduced at a more negative potential) which could probably be attributed to either an IR drop or electron-transfer hindrance considerations.

(37) Connor, P. A.; McQuillan, A. J. Langmuir 1999, 15, 2916-2921.

(38) Kosmulski, M. Langmuir 1997, 13, 6315-6320.

(39) Cantor, C. R.; Schimmel, P. R. Biophysical Chemistry; W. H. Freeman and Company: New York, 2002.

(40) Connor, P. A.; Dobson, K. D.; McQuillan, A. J. Langmuir 1999, 15, 24022408.

(41) Duggan, E. L.; Stevens, V. L.; Grunbaum, B. W. J. Am. Chem. Soc. 1957, $79,4859-4863$. a)

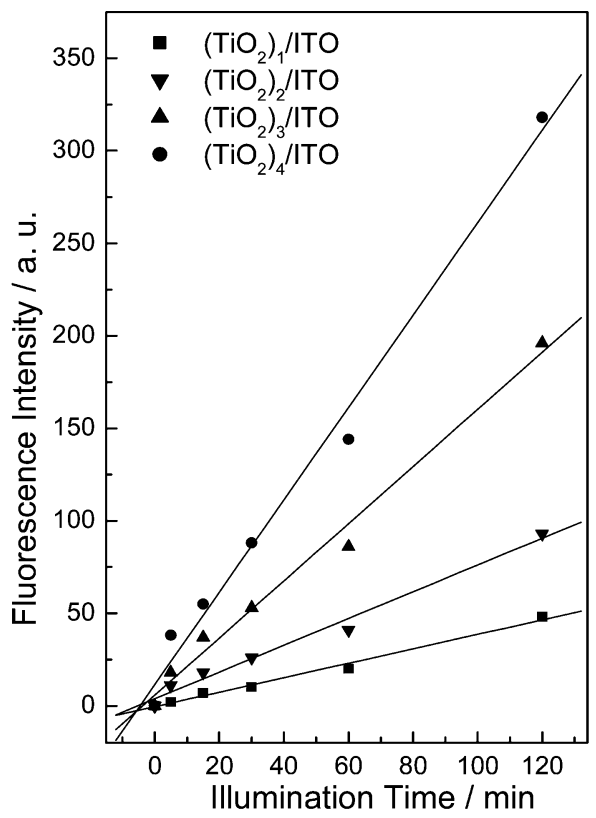

b)

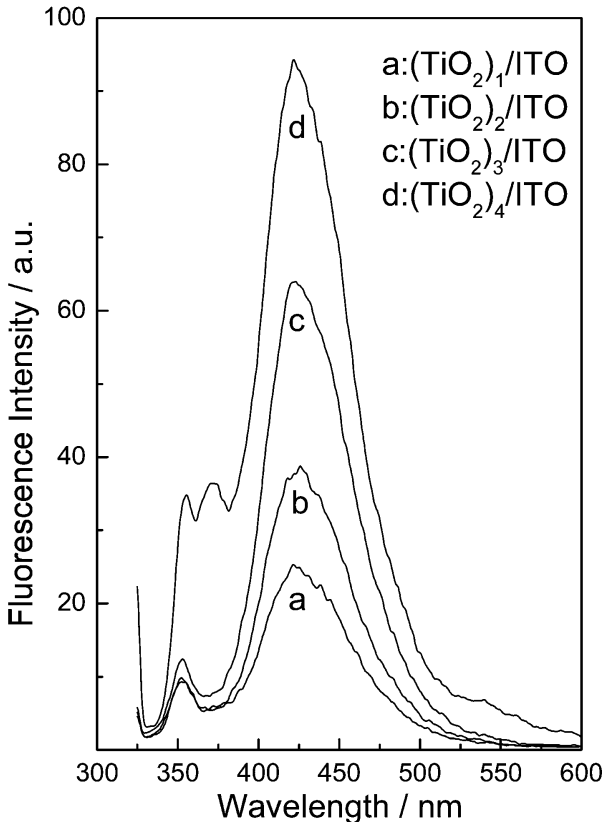

Figure 3. $\mathrm{OH} \cdot$ radical production on $\left(\mathrm{TiO}_{2}\right)$ i/lTO electrodes: (a) fluorescence intensity vs illumination time plot and (b) fluorescence intensity vs wavelength plot after $30 \mathrm{~min}$ of illumination.

The stability of the different ds-DNA/ $\left(\mathrm{TiO}_{2}\right) i / \mathrm{ITO}$ electrodes was also followed by SWV. The MB reduction current was monitored as a function of the electrode immersion time in a PBS buffer ( $\mathrm{pH}$ 7.4). A direct comparison with a simple ds-DNA/ITO electrode (adsorption in a citrate $\mathrm{pH} 3$ buffer overnight at $4{ }^{\circ} \mathrm{C}$, drying at $70{ }^{\circ} \mathrm{C}$ (room atmosphere) for $30 \mathrm{~min}$ ) was made. Whatever the $i$ value, the ds-DNA/ $\left(\mathrm{TiO}_{2}\right) i /$ ITO electrodes were found to be stable, because no $\mathrm{MB}$ reduction current evolution with time was observed. In contrast, ds-DNA/ITO electrodes (after treatment at $70{ }^{\circ} \mathrm{C}$ ) show a current decrease of $50 \%$ after $1 \mathrm{~h}$ of immersion. This observation, comparable to the adsorption behavior of organophosphate ligands on ITO, ${ }^{42}$ confirms that the

(42) Trammell, S. A.; Wimbish, J. C.; Odobel, F.; Gallagher, L. A.; Narula, P. M.; Meyer, T. J. J. Am. Chem. Soc. 1998, 120, 13248-13249. 


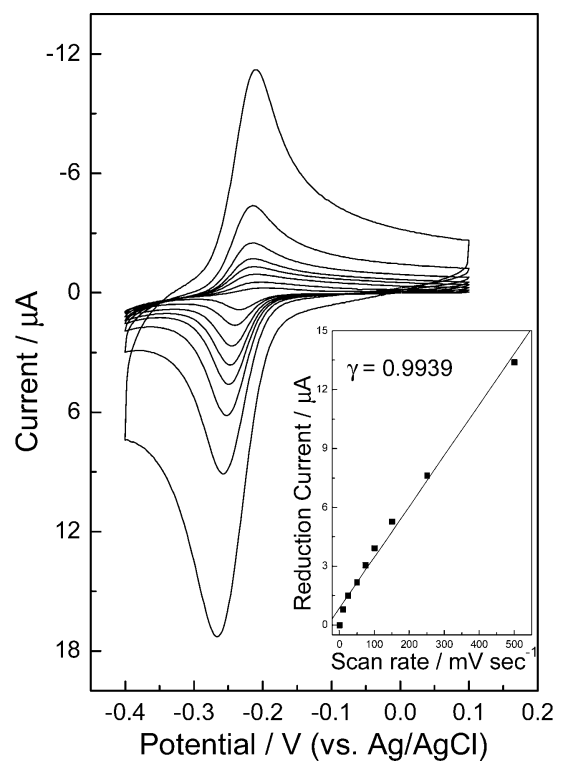

Figure 4. Cyclic voltammetry of $M B$ intercalated on a ds-DNA/ $\left(\mathrm{TiO}_{2}\right)_{1} / \mathrm{ITO}$ electrode. Overnight adsorption at $4{ }^{\circ} \mathrm{C}$ in a pH 2 buffer, $\mathrm{CV}$ (potential step $\Delta E_{\mathrm{s}}=5 \mathrm{mV}$, scan rate $=50 \mathrm{mV} / \mathrm{s}$ ). Inset: $\mathrm{MB}$ reduction current vs scan rate plot.

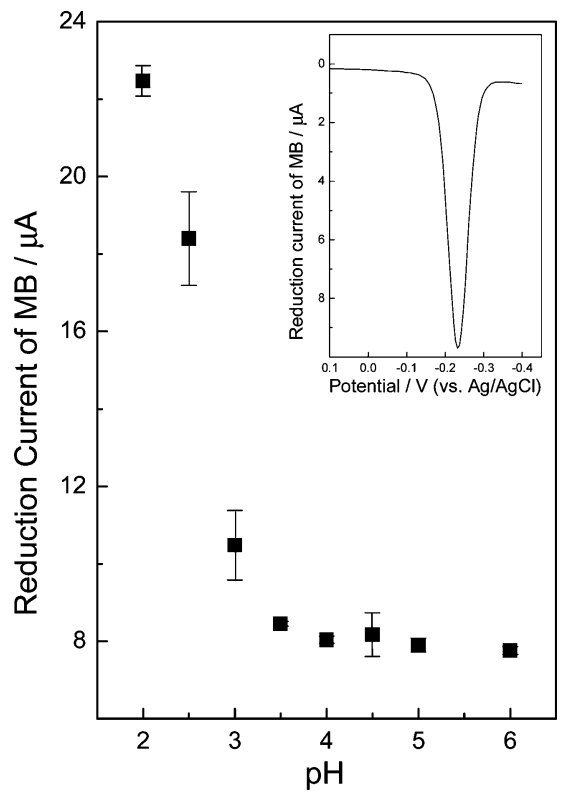

Figure 5. $\mathrm{pH}$ dependence of the $\mathrm{MB}$ reduction current for ds-DNA adsorption on $\left(\mathrm{TiO}_{2}\right)_{1} / \mathrm{ITO}$ electrodes at different $\mathrm{pHs}$. Overnight adsorption at $4{ }^{\circ} \mathrm{C}$ in different buffers (citric $(\mathrm{pH}: 2-3)$, acetic $(\mathrm{pH}$ : 3.5-5), and MES (pH: 6)) followed by a thermal treatment at $70^{\circ} \mathrm{C}$ for $30 \mathrm{~min}$, SWV (potential step $\Delta E_{\mathrm{s}}=5 \mathrm{mV}$, step amplitude $\Delta E_{\mathrm{sw}}=$ $25 \mathrm{mV}$, and frequency $f=10 \mathrm{~Hz}$ ).

presence of $\mathrm{TiO}_{2}$ coatings in conjunction with a thermal treatment enhance the ds-DNA/ $\left(\mathrm{TiO}_{2}\right) i / \mathrm{ITO}$ electrodes' stability.

ds-DNA Oxidation on $\mathrm{TiO}_{2} / \mathrm{ITO}$ Modified Electrodes. The proposed electrochemical sensor was tested for ds-DNA oxidation and damage monitoring in a physiological-like medium (PBS buffer ( $\mathrm{pH}$ 7.4)). The ds-DNA/ $\left(\mathrm{TiO}_{2}\right) i / \mathrm{ITO}$ electrodes prepared at $\mathrm{pH} 3$ were irradiated to photooxidize ds-DNA prior to $\mathrm{MB}$ labeling, because $\mathrm{MB}$ is known to be damaged by the photocatalytic activity of $\mathrm{TiO}_{2}$ materials. ${ }^{29}$ In addition, when irradiated with visible light (550-590 $\mathrm{nm}$ under specific conditions), MB also promotes singlet oxygen generation, then providing direct ds-DNA

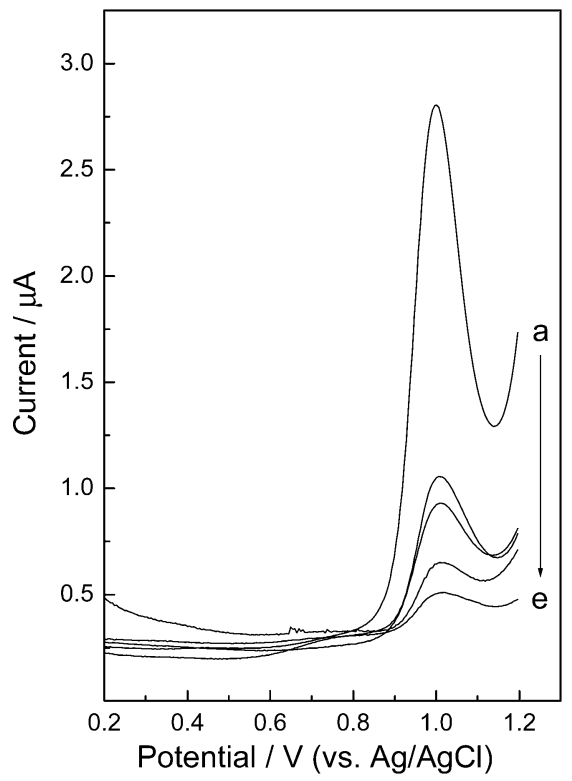

Figure 6. Detection of ds-DNA oxidation on a ds-DNA/( $\left(\mathrm{TiO}_{2}\right)_{3} / \mathrm{ITO}$ electrodes by SWV (potential step $\Delta E_{\mathrm{s}}=5 \mathrm{mV}$, step amplitude $\Delta E_{\mathrm{sw}}=25 \mathrm{mV}$, and frequency $f=10 \mathrm{~Hz}$ ) after different illumination times (i.e., irradiation at $360 \mathrm{~nm}$ for $0,10,30,45$, and $60 \mathrm{~min}$, curves from a to e, respectively). The peak situated at $1.0 \mathrm{~V}(\mathrm{vs} \mathrm{Ag} / \mathrm{AgCl})$ is related to guanine oxidation. 46

damage via deoxyguanosine oxidation. ${ }^{43-45}$ The photocatalytic activity of $\mathrm{TiO}_{2}$ films toward ds-DNA oxidation was evaluated by measuring the $\mathrm{MB}$ reduction current as a function of the illumination time for different ds-DNA/ $\left(\mathrm{TiO}_{2}\right) i /$ ITO electrodes. The oxidation of ds-DNA was also monitored by electrochemistry, as shown in Figure 6. Generally speaking, whatever the number of $\mathrm{TiO}_{2}$ coatings, the $\mathrm{MB}$ reduction current decreases with the illumination time.

As it happens, the evolution of the reduction current of $\mathrm{MB}$ adsorbed after the irradiation step follows a second-order kinetics rate law. Indeed, if the reduction current measured is proportional to the concentration of adsorbed ds-DNA, then the rate law obeys the equation

$$
\frac{1}{I}-\frac{1}{I_{0}}=k t
$$

as shown in Figure 7. ds-DNA oxidation is a complex phenomenon involving many reaction pathways. However, we propose in the Appendix a simple macroscopic model to account for this observed second-order kinetics. In the framework of this model, the secondorder rate constant $k$ is directly proportional to the photocatalytic ROS production $V \mathrm{p}$, directly proportional to the bimolecular rate constant of the oxidation of the ds-DNA by the ROS $\left(k_{1}\right)$ and directly proportional to the $\mathrm{OH}^{\bullet}$ lifetime $\tau_{\mathrm{OH}}$.

In conclusion, taking into account the different parameters discussed above, we decided to focus on ds-DNA/ $\left(\mathrm{TiO}_{2}\right)_{3} / \mathrm{ITO}$

(43) Suzuki, T.; Friesen, M. D.; Ohshima, H. Bioorg. Med. Chem. 2003, 11, 21572162.

(44) Ravanat, J. L.: Cadet, J. Chem. Res. Toxicol. 1995, 8, 379-388.

(45) Piette, J. J. Photochem. Photobiol., B 1991, 11, 241-260.

(46) Wang, J.; Cai, X. H.; Tian, B. M.; Shiraishi, H. Analyst 1996, 121, 965969. 


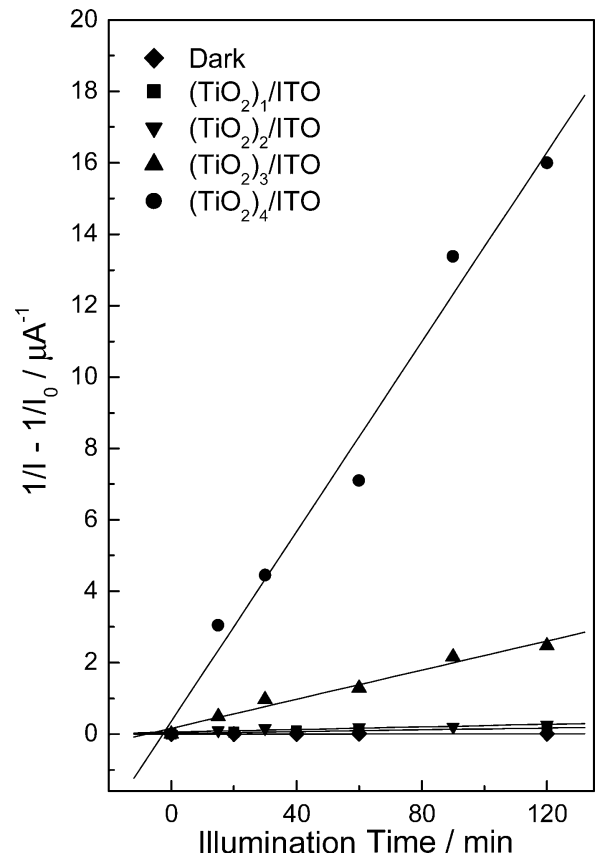

Figure 7. Detection of ds-DNA oxidation on ds-DNA/( $\left.\mathrm{TiO}_{2}\right) i / I T O$ electrodes: $M B$ reduction current vs UV illumination time plot according to eq 1 . Each data point is from a single electrode. All the electrodes used for a given value of $i$ were prepared in a single batch.

electrodes. In addition, to conserve the ds-DNA structure, the adsorption process was carried out in a $\mathrm{pH} 3$ citrate buffer. For these ds-DNA/ $\left(\mathrm{TiO}_{2}\right)_{3} / \mathrm{ITO}$ electrodes, we have $k=0.02 \mu \mathrm{A}^{-1}$ $\min ^{-1}$.

ds-DNA Oxidation Quenching by Antioxidant in Solution. The antioxidant property of glutathione to protect ds-DNA from oxidation was first examined. As shown in Figure 8, when the photomediated ds-DNA oxidation was carried out in the presence of glutathione $(5 \mathrm{mg} / \mathrm{mL})$, the electrochemical signal decreased more slowly than in the absence of glutathione. The second-order kinetic rate law in the presence of an antioxidant now reads according to the model presented in the Appendix,

$$
\frac{1}{I}-\frac{1}{I_{0}}=k_{\mathrm{app}} t
$$

where $k_{\text {app }}$ is inversely proportional to $k_{3}$, the bimolecular rate constant for the scavenging of the $\mathrm{OH}^{*}$ by the antioxidant. The apparent second-order rate constant $k_{\text {app }}$ is equal to $0.00156 \mu \mathrm{A}^{-1}$ $\min ^{-1}$.

The comparison of the data of Figure 8 gives a direct comparison of the quenching efficiency of the antioxidant compared to that of the solvent, and we get $k_{3}[\mathrm{AO}] \approx 12 k_{2}$.

In Figure 9, we compare the antioxidant efficiency of two model compounds, namely, glutathione and gallic acid. According to the model presented in the Appendix, the following equation,

$$
\left[\frac{1}{I_{t=30}}-\frac{1}{I_{t=0}}\right]^{-1}=a_{30}+b_{30}[\mathrm{AO}]
$$

should provide a linear relationship with the concentration of antioxidant. The slopes of the graphs of Figure 9 were found to

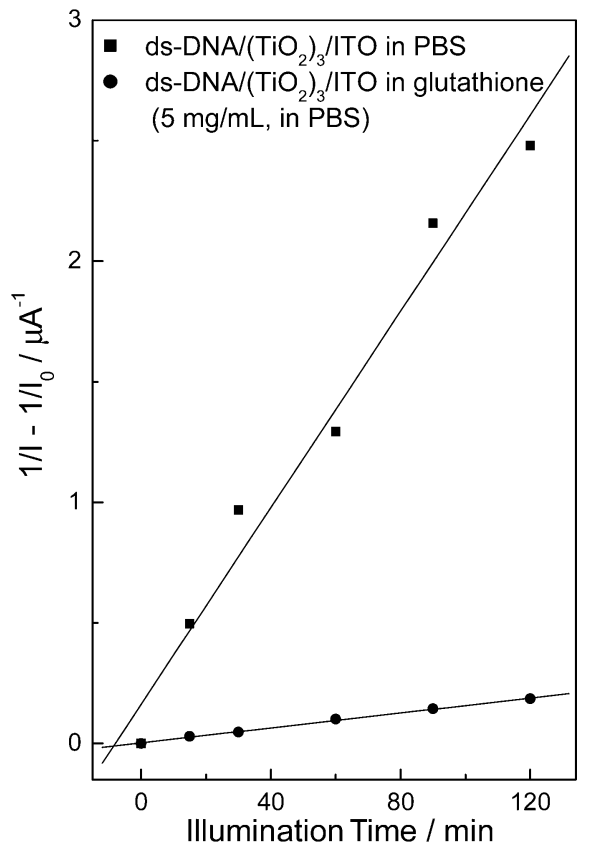

Figure 8. Detection of ds-DNA oxidation on ds-DNA/(TiO $)_{3} / / \mathrm{TO}$ electrodes: MB reduction current vs UV illumination time plot according to eq 1. Each data point is from a single electrode. All the electrodes used in this figure were prepared in a single batch.

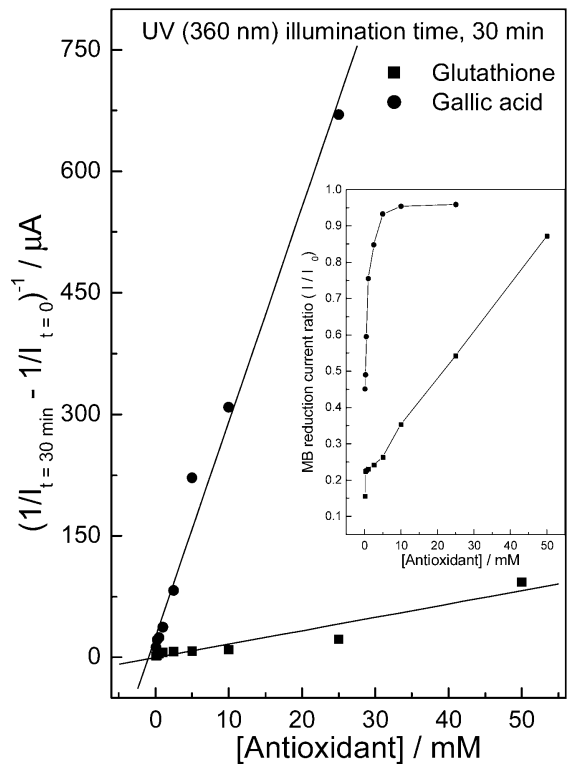

Figure 9. Detection of ds-DNA oxidation on ds-DNA/( $\left(\mathrm{TiO}_{2}\right)_{3} / \mathrm{ITO}$ electrodes: $\mathrm{MB}$ reduction current vs antioxidant concentration plot according to eq 3 for glutathione and gallic acid. Each data point is from a single electrode. All the electrodes used in this figure were prepared in a single batch. Inset: plot of the reduction current ratio of MB after ds-DNA oxidation in the presence of antioxidants over the MB reduction current of intact ds-DNA $\left(1 / /_{0}\right)$ vs the antioxidant concentration.

be equal to 1.65 and $26.5 \mu \mathrm{A} \mathrm{mM}^{-1}$ for glutathione and gallic acid, respectively. These values allow one to conclude that gallic acid is $\sim 16$ times more efficient as a ds-DNA-protecting antioxidant than is glutathione in our system.

\section{CONCLUSIONS}

We have demonstrated the possibility to study the antioxidant properties of natural compounds using an electrochemically based 
ds-DNA sensor. The proposed $\left(\mathrm{TiO}_{2}\right)_{3} / \mathrm{ITO}$ electrodes were found to be suitable for the different and complementary tasks that include ds-DNA immobilization, $\mathrm{OH}^{\bullet}$ radical photogeneration, and electrode material to study $\mathrm{MB}$ reduction. It was also shown that the use of $\mathrm{MB}$ as both ds-DNA intercalant and redox mediator is a suitable method to follow ds-DNA damage via sensitive voltammetric methods such as SWV. This redox probe, able to detect small ds-DNA structure changes, allows a direct analysis and comparison of the antioxidant capacities of specific natural molecules. A simple macroscopic kinetic model is proposed to quantify the antioxidant efficiency for ds-DNA protection.

\section{APPENDIX}

In this part, we shall address the kinetics of surface-bound dsDNA oxidation on $\mathrm{TiO}_{2} / \mathrm{ITO}$ electrodes. We have seen in Figure 3 that the rate $V_{\mathrm{p}}$ of $\mathrm{OH} \cdot$ production is a constant. In a volume defined as a thin layer above the electrode surface, we could then consider the following mechanisms:

$$
\begin{gathered}
\mathrm{TiO}_{2} \stackrel{V_{\mathrm{p}}}{\longrightarrow} \mathrm{OH}^{\bullet} \\
\mathrm{OH}^{\bullet}+\mathrm{DNA}^{\stackrel{k_{1}}{\longrightarrow}} \mathrm{DNA}_{\mathrm{OX}} \\
\mathrm{OH}^{\bullet}+\mathrm{H}_{2} \mathrm{O} \stackrel{k_{2}}{\longrightarrow} \mathrm{X}
\end{gathered}
$$

The third step is a generic manner to consider the quenching of $\mathrm{OH} \bullet$ by all the other species, where $k_{2}$ is a pseudo-first-order rate constant. The steady-state approximation for the $\mathrm{OH}^{\bullet}$ radical is then

$$
\frac{\mathrm{d}\left[\mathrm{OH}^{\bullet}\right]}{\mathrm{d} t}=V_{\mathrm{p}}-k_{1}\left[\mathrm{OH}^{\bullet}\right][\mathrm{DNA}]-k_{2}\left[\mathrm{OH}^{\bullet}\right]=0
$$

that yields

$$
\left[\mathrm{OH}^{\bullet}\right]=\frac{V_{\mathrm{p}}}{k_{2}+k_{1}[\mathrm{DNA}]}
$$

Then, the consumption rate of surface-bound ds-DNA is

$$
-\frac{\mathrm{d}[\mathrm{DNA}]}{\mathrm{d} t}=k_{1}\left[\mathrm{OH}^{\bullet}\right][\mathrm{DNA}]=\frac{k_{1} V_{\mathrm{p}}[\mathrm{DNA}]}{k_{2}+k_{1}[\mathrm{DNA}]}
$$

If $k_{2} \ll k_{1}[\mathrm{DNA}]$, then we have

$$
-\frac{\mathrm{d}[\mathrm{DNA}]}{\mathrm{d} t}=V_{\mathrm{p}}
$$

and we should get an apparent zero-order kinetics; i.e., the concentration of ds-DNA on the electrode should decrease linearly with time. If $k_{2} \gg k_{1}$ [DNA], then we have

$$
-\frac{\mathrm{d}[\mathrm{DNA}]}{\mathrm{d} t}=\frac{k_{1} V_{\mathrm{p}}}{k_{2}}[\mathrm{DNA}]
$$

and we should get an apparent first-order kinetics, and the concentration of ds-DNA on the electrode should follow an exponential decay.

However, the experimental data show that the kinetics is second-order.

One aspect of the present experiment is that the $\mathrm{OH}^{\bullet}$ radical has a very short lifetime. Therefore, we could consider two types of $\mathrm{OH}^{\bullet}$ radicals, those produced on that part of the electrode covered by ds-DNA $\left(\mathrm{OH}_{\mathrm{a}}{ }^{\circ}\right)$ and those on that part coated by oxidized ds-DNA $\left(\mathrm{OH}_{\mathrm{b}}{ }^{\circ}\right)$.

Let's call $c_{\max }$ the original surface concentration of ds-DNA after the coating step. At time $t$, this concentration becomes $\theta c_{\max }$, where $\theta$ is the surface coverage. The mechanism considered above can now be written as

$$
\begin{gathered}
\mathrm{TiO}_{2} \stackrel{V_{\mathrm{p}}}{\longrightarrow} \mathrm{OH}_{\mathrm{a}} \cdot \mathrm{OH}_{\mathrm{b}} \\
\mathrm{OH}_{\mathrm{a}} \cdot+\mathrm{DNA} \stackrel{k_{1}}{\longrightarrow} \mathrm{DNA}_{\mathrm{OX}} \\
\mathrm{OH}_{\mathrm{a}} \cdot \mathrm{H}_{2} \mathrm{O} \stackrel{k_{2}}{\longrightarrow} \mathrm{X}
\end{gathered}
$$

The rate of production of $\mathrm{OH}_{\mathrm{a}}{ }^{\bullet}$ is, therefore, $\theta V_{\mathrm{p}}$. The steadystate approximation for $\mathrm{OH}_{\mathrm{a}}{ }^{\bullet}$ is then given by

$$
\frac{\mathrm{d}\left[\mathrm{OH}_{\mathrm{a}}^{\bullet}\right]}{\mathrm{d} t}=\theta V_{\mathrm{p}}-k_{1} \theta c_{\max }\left[\mathrm{OH}_{\mathrm{a}}^{\cdot}\right]-k_{2}\left[\mathrm{OH}_{\mathrm{a}}^{\bullet}\right]=0
$$

which yields

$$
\left[\mathrm{OH}_{\mathrm{a}}^{\cdot}\right]=\frac{\theta V_{\mathrm{p}}}{k_{2}+k_{1} \theta c_{\max }} \approx \frac{\theta V_{\mathrm{p}}}{k_{2}}
$$

if we assume that $\mathrm{OH}_{\mathrm{a}} \cdot$ reaction with ds-DNA is slower than the quenching by the solvent. The rate of consumption of surfacebound ds-DNA is then

$$
-\frac{\mathrm{d}[\mathrm{DNA}]}{\mathrm{d} t}=k_{1}\left[\mathrm{OH}_{\mathrm{a}}{ }^{\circ}\right][\mathrm{DNA}]=\frac{k_{1} V_{\mathrm{p}}}{k_{2}} c_{\max } \theta^{2}=-\frac{\mathrm{d} \theta}{\mathrm{d} t} C_{\max }
$$

If the reduction current is proportional to the surface concentration of ds-DNA, then the integration of this equation yields

$$
\frac{1}{I}-\frac{1}{I_{0}}=\frac{k_{1} V_{\mathrm{p}}}{I_{0} k_{2}} t=k t
$$

We obtain, then, a second-order rate law. In addition, this model accounts for the results of Figure 7 , where we see that $V_{\mathrm{p}}$ increases with the number of layers of $\mathrm{TiO}_{2}$. It is interesting to notice that $k_{2}$ is a pseudo-first-order rate constant and that $\tau_{\mathrm{OH}^{*}}=$ $k_{2}{ }^{-1}$ is the $\mathrm{OH}^{\bullet}$ radical lifetime in solution in the vicinity of the electrode.

In the presence of antioxidant, $\mathrm{AO}$, the reaction mechanism should consider an additional reaction,

$$
\mathrm{OH}_{\mathrm{a}} \cdot \mathrm{AO} \stackrel{k_{3}}{\longrightarrow} \mathrm{AO}_{\mathrm{OX}}
$$


and the rate of consumption of ds-DNA is then

$$
\frac{1}{I}-\frac{1}{I_{0}}=\frac{k_{1} V_{\mathrm{p}}}{I_{0}\left(k_{2}+k_{3}[\mathrm{AO}]\right)} t=k_{\mathrm{app}} t
$$

In Figure 9, we have measured the reduction current of $\mathrm{MB}$ after an irradiation of $30 \mathrm{~min}$ for different concentrations of antioxidant, and the plot

$$
\left[\frac{1}{I_{t=30}}-\frac{1}{I_{t=0}}\right]^{-1}=a_{30}+b_{30}[\mathrm{AO}]
$$

is proportional to $[\mathrm{AO}]$.

This simple macroscopic model allows the determination of the efficiency of the antioxidant molecules at protecting ds-DNA.
Abbreviations. ds-DNA, double stranded DNA; ITO, indium tin oxide; MB, Methylene Blue; ROS, reactive oxygen species; $\mathrm{CV}$, cyclic voltammetry; SVW, square wave voltammetry.

\section{ACKNOWLEDGMENT}

Dr. J. Kiwi and Dr. P. Wang (Laboratory of Photonics and Interfaces, EPFL) are thanked for fruitful discussions and collaboration. B. Senior (Centre Interdisciplinaire de Microscopie Electronique, EPFL) is also acknowledged for SEM studies. The CTI is acknowledged for financial support through Grant No. CTI6425.1 .

\section{SUPPORTING INFORMATION AVAILABLE}

$\mathrm{CV}$ of $\mathrm{MB}(10 \mu \mathrm{M}$ in PBS buffer, $\mathrm{pH} 7.4)$ performed on a $(\mathrm{TiO})_{3} / \mathrm{ITO}$ electrode at different scan rates. This material is available free of charge via the Internet at http://pubs.acs.org.

Received for review May 27, 2005. Accepted August 3, 2005.

AC0509298 